\title{
A SPIRITUAL FATHER FOR THE WHOLE CHURCH: THE UNIVERSAL APPEAL OF ST. EPHRAEM THE SYRIAN
}

\author{
SIDNEY H. GRIFFITH \\ INSTITUTE OF CHRISTIAN ORIENTAL RESEARCH \\ THE CATHOLIC UNIVERSITY OF AMERICA
}

\begin{abstract}
I
In an encyclical letter issued on 5 October 1920, Pope Benedict XV proclaimed St. Ephraem the Syrian a Doctor of the Universal Church. ${ }^{1}$ This accolade may be seen as in some ways the culmination in Rome of a new fame in the twentieth century for Syria's 'Harp of the Holy Spirit,' already widely acclaimed in east and west in medieval times. It was due to efforts exerted already for some two centuries by a number of scholars in the west to bring out modern editions of Ephraem's works. One thinks initially of the publication in the eighteenth century of the six-volume Roman edition of the works attributed to Ephraem in Greek, Syriac, and Latin. ${ }^{2}$ While the Greek and Latin texts had long been known in the west, the publication of Ephraem's works in Syriac,
\end{abstract}

1 See Benedict XV, "Principi Apostolorum Petro," Acta Apostolicae Sedis 12 (1920), pp. 457-453.

2 See J.S. Assemani (ed.), Sancti Patris Nostri Ephraem Syri Opera Omnia quae exstant Graece, Syriace, Latine, 6 vols. (Rome, 1732-46). 
the only language in which he is known to have written, brought the first glimpse of the poet's true genius to western Christians. The Syriac works, with Latin translations, were included in volumes IV to VI of the Editio Romana. They are largely the work of Étienne Awad Assemani (1709-82) and Pierre Mobarak, S.J. (1660-1742), Maronite scholars who worked in close association with J.S. Assemani (1687-1768) and others in the Maronite College in Rome and the Vatican Library. ${ }^{3}$ While later scholars have sometimes been scathing in their comments about the quality of this edition, the fact remains that for all practical purposes it offered the first glimpse of the genuine works of Ephraem the Syrian to Europeans who had hitherto known only the works of Ephraem Graecus and their numerous translations and adaptations in other languages. It is surprising that in the nineteenth century the Abbé Migne did not include any of the published works of Ephraem in either the Patrologia Graeca or the Patrologia Latina.

In subsequent years, beginning in the nineteenth century, and reaching well into the twentieth century, scholars in England, Belgium, and other parts of Europe, making use of the numerous manuscripts recently acquired in the west, made major strides in publishing the rest of the Syriac works attributed to Ephraem. ${ }^{4}$ T.J. Lamy's edition of his Hymns and Homilies ${ }^{5}$ at the turn of the century brought Ephraem's works in Syriac into the mainstream of religious discourse in Europe, and arguably led directly to Pope Benedict XIV's proclamation in 1920. But already it was becoming clear that the first publications of Ephraem's Syriac works left much to be desired in terms of the quality of the editions of the texts; many of them were not based on the best available manuscripts, and the work of many of the editors did not satisfy the requirements of truly critical editions. To remedy this situation, Dom Edmund Beck, O.S.B. (1902-91) began in 1955,

${ }^{3}$ See Pierre Raphael, Le rôle du Collège Maronite Romain dans l'orientalisme aux XVIIe et XVIIIe siècles (Beyrouth: Université Saint Joseph, 1950), esp. pp. 123-36, 137-9, 145-8.

${ }^{4}$ See the details in Joseph Melki, "S. Ephrem le Syrien, un bilan de l'édition critique," Parole de l'Orient 11 (1983): 3-88; S.P. Brock, "A Brief Guide to the Main Editions and Translations of the Works of St. Ephrem," The Harp 3 (1990): 7-29.

5 T.J. Lamy, Sancti Ephraem Syri Hymni et Sermones, 4 vols. (Malines, 1882-1902). 
and continued for the next quarter century, to publish critical editions and German translations of the genuine, Syriac works of Ephraem in the Louvain series Corpus Scriptorum Christianorum Orientalium. ${ }^{6}$ While Beck has not been alone in the task of editing and publishing Ephraem's works in the twentieth century, the sheer volume of his output in this enterprise makes his name almost synonymous with the production as it were of the 'complete works' of Ephraem the Syrian.

The modern publication of the Syriac works of Ephraem has been accompanied by a crescendo in the number of studies devoted to them, and to his life and thought more generally. ${ }^{7}$ The effect of all this attention has been gradually to bring Ephraem's Syriac works into the mainstream of modern patristic scholarship, although one can even now consult the index of too many studies of early Christian thought in areas on which he wrote extensively and still not find a mention of his name. ${ }^{8}$

\section{II}

Well within the patristic period itself Ephraem's reputation as a holy man, poet, and theologian of note was widely proclaimed, well beyond the borders of his native Syria and the territories where Syriac was spoken. Within fifty years of his death, Palladius included a notice of Ephraem among the ascetic saints whose memory he celebrated in the Lausiac History. ${ }^{9}$ Sozomen, the early fifth century historian, celebrated Ephraem's memory as a popular ecclesiastical writer. He said of Ephraem's works, "They were

${ }^{6}$ Beck published his last edition in 1979 (CSCO 412 \& 413). In the end, in addition to numerous other studies, he produced 19 volumes of editions and translations of Syriac works attributed to Ephraem.

7 The surest way bibliographically to control what is being published in Ephraem studies is to consult the on-going classified bibliography in Syriac studies compiled by Sebastian P. Brock in Parole de l'Orient: 1960-70 - 4 (1973): 393-465; 1971-80 - 10 (1981-82): 291-412; 1981-85 - 14 (1987): 289-360; 1986-90 - 17 (1992): 211-301, now compiled in one separately published volume: Syriac Studies: A Classified Bibliography, 1960-1990 (Kaslik: Parole de l'Orient, 1996).

${ }^{8}$ A notable case in point is R. P. C. Hanson, The Search for the Christian Doctrine of God (Edinburgh: T \& T Clark, 1988).

9 See C. Butler, The Lausiac History of Palladius, 2 vols. (Texts and Studies 6; Cambridge, 1898 \& 1904), vol. II, 126-7. 
translated into Greek during his lifetime, ... and yet they preserve much of their original force and power, so that his works are not less admired when read in Greek than when read in Syriac." 10 Even Saint Jerome, a man not always ready with praise for the work of others, claimed to recognize Ephraem's theological genius in a Greek translation he read of a book by Ephraem on the Holy Spirit. ${ }^{11}$ Later, in Byzantium, so important a monastic figure as Theodore of Stoudios (759-826) held up the example of Ephraem for the inspiration of his monks. In a sermon he put forward the ascetical example of John Chrysostom and of "Ephraem, famous in song." 12 In his Testament, Theodore confessed his acceptance of the example of the oriental monks, especially Barsanuphius, Antony, Ephraem and others. ${ }^{13}$ But surely the most striking testimony to the Syrian saint's popularity in patristic and medieval times is the fact that in the Clavis Patrum Graecorum, the number of pages it takes to list the works in Greek attributed to Ephraem is second only to the number of pages devoted to listing the works of the ever popular John Chrysostom! ${ }^{14}$ In medieval Europe, these ascetical homilies, translated into Latin, found a home in many monastic

10 J. Bidez \& G. H. Hansen (eds.), Sožmenus, Kirchengeschichte (Griechische Christliche Schriftsteller, no. 5.; Berlin, 1960) 127-30.

11 See E.C. Richardson (ed.), Hieronymus, Liber de Viris Inlustribus (Texte und Untersuchungen 14.; Leipzig, 1896) 51.

${ }^{12}$ See S. Theodori Studitae Parva Catechesis, Sermon 42, in A. Mai (ed.), Nova Patrum Bibliotheca, vol. IX (Typis Collegii Urbani, Rome, 1888) 102.

${ }^{13}$ See S. Theodori Studitae Testamentum, in Patrologia Graeca 99, col. 1815.

14 See M. Geerard, Clavis Patrum Graecorum, vol. II (Turnhout: Brepols, 1974) 366-468. On the texts of Ephraem Graecus, see the pioneering studies of Democratie Hemmerdinger-Iliadou, "L'authenticité sporadique de l'Éphrem grec," in Akten des XI. internationalen ByzantinistenKongresses (München, 1960) 232-6; "Les doublets de l'édition de l'Éphrem grec par Assemani," Orientalia Christiana Periodica 24 (1958): 371-82; "Vers une nouvelle édition de l'Éphrem grec," in Studia Patristica 3 (1961): 80019; "Les citations évangéliques de l'Éphrem grec," Byzantina 4 (1973): 315-73; "Éphrem: versions grecque, latine et slave: addenda et corrigenda," Epeteris Hetairesias Byzantinon Spoudon (1975-76): 320-59. See also J. Kirchmeyer \& D. Hemmerdinger-Illiadou, "Saint Éphrem et le 'Liber Scintillarum', Recherches de Science Religieuse 46 (1958): 545-50. Selected works of Ephraem Graecus, and their relationship to Syriac works of Ephraem, are the subject of a forthcoming Ph.D. dissertation at Princeton Theological Seminary by Wonmo Suh. 
libraries..$^{15}$ In the monasteries of the Holy Land after the Arab conquest, some of these same Greek works attributed to Ephraem were among the earliest texts translated into Christian Arabic by the 'Melkites' who lived in the world of Islam. ${ }^{16}$ In Kievan Rus', the Greek works of Ephraem were especially dear to the influential monk Abraham of Smolensk, whose principal disciple even adopted the religious name Ephraem. From these beginnings Ephraem's name and fame spread widely in Russia. ${ }^{17}$

\section{III}

One notices immediately, however, that these testimonies to Ephraem's great popularity throughout the medieval Christian world all refer to works in Greek. In spite of the fact that Sozomen testifies that Ephraem's works were translated into Greek during the Syrian's lifetime, one of the effects of the modern recovery of his genuine works in Syriac is that scholars have come to recognize that there can be only a spiritual relationship between the writers of the works attributed to Ephraem in Greek and those attributed to

${ }^{15}$ For studies of Ephraem Latinus see August C. Mahr, Relations of Passion Plays to St. Ephrem the Syrian (Columbus, Ohio: Wartburg Press, 1942); G. Bardy, "Le souvenir de saint Éphrem dans le haut-moyen âge latin," Revue du Moyen Age Latin 2 (1946): 297-300; Daniel Verhelst, "Scarpsum de Dictis Sancti Efrem prope Fine Mundi," in R. Lievens et al., (eds.), Pascua Mediaevalia; Studies voor Prof. Dr. J.M. De Smet (Leuven, 1983) 518-28; T. S. Pattie, "Ephraem the Syrian and the Latin Manuscripts of 'De Paenitentia'," The British Library Journal 13 (1987): 124; idem, 'Ephraem's 'On Repentance' and the Translation of the Greek Text into Other Languages," The British Library Journal 16 (1990): 174-5.

${ }^{16}$ See W. Heffening, "Die griechische Ephraem-Paraenesis gegen das Lachen in arabischer Übersetzung," Oriens Christianus 3rd series, 2 (1927): 94-119; J. M. Sauget, "Le dossier éphrémien du manuscrit arabe Strasbourg 4226 et de ses membra disiecta," Orientalia Christiana Periodica 42 (1978): 426-58; Samir Khalil, "L’Éphrem arabe, état des travaux," Symposium Syriacum 1976 (Orientalia Christiana Analecta, 205; Rome, 1978) 229-40. See also Delio Vania Proverbio, "Auctarium au dossier copte de l'Éphrem grec," Orientalia 66 (1997): 78-85.

${ }^{17}$ See G. P. Fedotov, The Russian Religious Mind: Kievan Christianity, the 10th to the 13th Centuries (New York, 1960) 158-75; G. Podskalsky, Christentum und theologische Literatur in der kiever Rus' (988-1237) (Munich, 1982) 50, 101-4, 140; I. Ogren, The Paraeneses of Ephraem the Syrian: History of the Slavonic Translation [Russian] (Uppsala, 1989). 
him in Syriac. What is more, in the biographical tradition, an examination of the Greek and Syriac sources for the saint's life reveals two very different personae. For convenience, one might style the two images of the saint as the 'icon of Ephraem Byzantinus' and the 'portrait of Ephraem Syrus.' ${ }^{18}$ They depict saints of very different character.

The icon of Ephraem Byzantinus owes its main features to writers in the Graeco-Syrian monastic communities of the fifth and sixth centuries. They transmitted Ephraem's works in both Greek and Syriac, even composing new hymns and homilies in his style and under his name. They also composed the Syriac Vita Ephraemi and a Syriac work attributed to Ephraem and presented as his Testament, two works that together are the principal sources for the literary icon of Ephraem Byzantinus. ${ }^{19}$

According to the Vita, Ephraem lived in a cave on a mountain near Edessa, from which he emerged only at the end of his life to help victims of the plague in that city. Incidentally, he is said to have composed some doctrinal hymns and exegetical homilies in Syriac, and then only to combat the popular heresy of Bar Daysān (154-222), a native of Edessa. In this account, Ephraem even ensured the authenticity of his style of monastic life by a visit to the deserts of Egypt, where he is said to have met the Macarian hero, Bishoi. ${ }^{20}$ Afterward, according to the Vita, he guaranteed his

18 See Edward G. Mathews, Jr., "The Vita Tradition of Ephrem the Syrian, the Deacon of Edessa," Diakonia 22 (1988-9): 15-42; Sidney H. Griffith, "Images of Ephraem: the Syrian Holy Man and his Church," Traditio (1989-90): 7-33; Joseph P. Amar, "Byzantine Ascetic Monachism and Greek Bias in the Vita Tradition of Ephrem the Syrian," Orientalia Christiana Periodica 58 (1992): 123-56.

19 See Joseph P. Amar, "The Syriac Vita Tradition of Ephrem the Syrian," (Ph.D. dissertation; Washington, D.C.: The Catholic University of America, 1988). A convenient summary in Latin of the traditional lives of St. Ephraem is readily available in "De S. Ephrem Syro Edessae in Mesopotamia," Acta Sanctorum February 1 (Paris, 1863) 49-78. On the Testament of Ephraem, its inauthenticity, and its debt to the tradition that produced the Vita, see Amar, "The Syriac Vita Tradition," and "Byzantine Ascetic Monachism and Greek Bias." See also E. Beck, Des heiligen Ephraem des Syrers Sermones IV (CSCO 334 \& 335; Louvain: Secrétariat du CorpusSCO, 1973), vol. 335, xi-xiv.

20 On this incident in the Vita, see H. J. Polotsky, "Ephraems Reise nach Aegypten," Orientalia 2 (1933): 269-74; M. J. Blanchard, "The Coptic 
orthodoxy for the emperor's church by an ad limina visit to St. Basil of Caesarea, even fleeing priestly ordination at Basil's hands, in good monastic style, although accepting the diaconate. ${ }^{21}$ Parallel to this account, Ephraem's Testament reflects the world-view of a monastic hero, a desert solitary of the type whose stories John of Ephesus or Cyril of Scythopolis might have told. This literary, or verbal icon, in fact must lie behind the best-known artistic presentation of St. Ephraem, the composition known as the 'Dormition of Ephraem Syrus', in which Ephraem's body, lying on a funeral slab, surrounded by mourners, is the focal point of a tableau made up of other scenes from a cycle of hermits, stylites, and recluses. Exemplars of this composite scenario are in both the Vatican Gallery and the monastery of Dokheiarious on Mt. Athos. It is a perfect presentation of the profile of Ephraem Byzantinus. ${ }^{22}$

The portrait of Ephraem Syrus, which the recovery of Ephraem's genuine works in Syriac and other texts in Syriac allow the modern scholar to project, leaves behind the testimony of the monastic hagiographers in Byzantium. From the Syriac texts Ephraem emerges as a 'teacher' (malpana $\hat{)}$ ) and a poet, who for the majority of his almost seventy years served the bishops of Nisibis as a catechist, biblical exegete, and liturgical composer. For the last ten years of his life he served the bishop of Edessa in the same capacity. He was not a monk, although, as an unmarried man, he was probably a 'single' person (ihîidayyâ) dedicated to God's service. ${ }^{23}$ He refers to himself as a 'herdsman' ('allanâa), a member of the shepherd-bishop's pastoral staff. In the last of his Hymns against Heresies he wrote of himself when he prayed,

O Lord, may the works of your herdsman ('allanâ) not be cheated.

Heritage of St. Ephrem the Syrian,” in T. Orlandi \& D. J. Johnson (eds.), Acts of the Fifth International Congress of Coptic Studies, Washington, 12-15 August 1992, 3 vols. (Roma: C.I.M., 1993), vol. II, 37-51.

21 See O. Rousseau, "La rencontre de saint Ephrem et de saint Basile,” L'Orient Syrien 2 (1957): 261-284; 3 (1958): 73-90.

22 See John R. Martin, "The Death of Ephraim in Byzantine and Early Italian Painting," The Art Bulletin 33 (1951): 217-25.

${ }^{23}$ On the significance of this title see Sidney H. Griffith, "Asceticism in the Church of Syria: the Hermeneutics of Early Syrian Monasticism," in Vincent L. Wimbush \& Richard Valantasis (eds.), Asceticism (New York: Oxford University Press, 1995) 220-45. 
I will not then have troubled your sheep, but as far as I was able,

I will have kept the wolves away from them, and I will have built, as far as I was capable,

enclosures of madrāshê

for the lambs of your flock.

I will have made a disciple

of the simple and unlearned man.

And I will have given him a strong hold

on the herdsmen's ('allānê) staff,

the healers' medicine,

and the disputants' armor. ${ }^{24}$

Ephraem is not more specific about his own position in the church. It is not impossible that he was in fact a deacon, although no early Syriac text explicitly identifies him as such. Clearly it was the renown of his teaching, and of the holiness of his life, that inspired Syriac writers to celebrate the fame of Ephraem the Syrian, the teacher par excellence, and that prompted the monastic hagiographers in the Greek-speaking world, and those under their influence, to fashion the image of Ephraem Byzantinus.

\section{IV}

[10] Ephraem's works in Syriac are almost all metrical compositions, or Kunstprosa, that is to say poetry, in some sense of the word. It is true that he wrote some works in more straightforward prose as well, such as his commentaries on Genesis, Exodus and the Diatessaron, ${ }^{25}$ along with the collection of polemical texts which

${ }^{24}$ Edmund Beck, Des heiligen Ephraem des Syrers Hymnen contra Haereses (CSCO 169 \& 170; Louvain: Secrétariat du CorpusSCO, 1957), vol. 169, 56:10\&11, pp. 211-2.

25 See R.M. Tonneau, Sancti Ephraem Syri in Genesim et in Exodum commentarii (CSCO 152 \& 153; Louvain: Peeters, 1955); Edward G. Mathews, Jr., \& Joseph P. Amar, St. Ephrem the Syrian: Selected Prose Works; Commentary on Genesis, Commentary on Exodus, Homily on our Lord, Letter to Publius (Kathleen McVey, ed., The Fathers of the Church 91; Washington, D.C.: The Catholic University of America Press, 1994). See also Louis Leloir, Saint Ephrem: Commentaire de l'évangile concordant; texte syriaque (MS Chester Beatty 709) (Chester Beatty Monographs 8; Dublin, 1963), idem, Saint Ephrem: Commentaire de l'évangile concordant; texte syriaque (MS Chester 
generally goes under the title given them by the editor of many of them, the so-called Prose Refutations. ${ }^{26}$ But there is no doubt that his particular genius comes to full flower in the poetic mêmrê and madräshê that he penned, or the 'homilies' and 'hymns' as they are conventionally called in the west. ${ }^{27}$ Here we meet the real Ephraem, who expressed his thoughts in measured lines of verse, usually in isosyllabic cola, which, in the madräshê, are arranged in stanzas, after each one of which a response ('unitâ) is usually repeated. ${ }^{28}$ Ephraem seems to have been genuinely proud of his madräshê; he sometimes 'signed' them by the acrostic device of beginning each successive stanza with words whose first Syriac letters in sequence spell out his name. ${ }^{29}$

Ephraem's hymns and verse homilies often had a liturgical setting. St. Jerome says that in some churches they were recited after the scripture lessons in the divine liturgy. ${ }^{30}$ The recitation was chanted to the accompaniment of the lyre (kennara $\hat{)}$, on the model of David, the Psalmist. ${ }^{31}$

Beatty 709), folios additionnels (Leuven/Paris: Peeters, 1990); Carmel McCarthy, Saint Ephrem's Commentary on Tatian's Diatessaron; an English Translation of Chester Beatty MS 709 with Introduction and Notes Journal of Semitic Studies Supplement 2; Oxford: Oxford University Press on Behalf of the University of Manchester, 1993). See also Louis Leloir, Éphrem de Nisibe: Commentaire de l'évangile concordant our Diatessaron, traduit du Syriaque et de l'Arménien (Sources Chrétiennes 121; Paris: Les Éditions du Cerf, 1966).

${ }^{26}$ See C. W. Mitchell, S. Ephraim's Prose Refutations of Mani, Marcion, and Bardaisan, 2 vols. (London/Oxford: Williams and Norgate, 1912 \& 1921).

27 See the convenient presentation of the titles of Ephraem's Syriac works listed by genre in Brock, "A Brief Guide to the Main Editions and Translations," 17-28.

${ }^{28}$ For a discussion of the madrāshâ as a literary form see Michael Lattke, "Sind Ephraems Madrāse Hymnen?" Oriens Christianus 73 (1989): $38-43$.

${ }^{29}$ See Andrew Palmer, "St Ephrem of Syria's Hymn on Faith 7: an ode on his own name," Sobornost 17 (1995): 28-40.

30 "Ephrem, Edessenae ecclesiae diaconus, multa Syro sermone conposuit, et ad tantam venit claritudinem, ut post lectionem Scriptuarum publice in quibusdam ecclesiis eius scripta recitentur." E. C. Richardson, Hieronymus, Liber de Viris Inlustribus (Leipzig, 1896) 51.

${ }^{31}$ See Andrew Palmer, "“A Lyre without a Voice,' the Poetics and the Politics of Ephrem the Syrian," ARAM 5 (1993): 371-99. 
We learn from Jacob of Sarug's verse homily on Ephraem, 'the Teacher', how important the correct performance of his madräshê was for the busy malpanâ of Nisibis and Edessa. He reportedly spent time and energy rehearsing the singers who would perform them in church. And what is more, according to Jacob, he insisted that women take their rightful place in the church's choirs. On this subject, Jacob spoke of Ephraem as "a second Moses for women," 32 and he addressed Ephraem as follows:

In you, even our sisters were encouraged to sing

[God's]

praises, although it was not permissible for

women to speak in church. (1 Cor. 14:34)

Your teaching opened the closed mouth of the daughters

of Eve, and now the congregations of the glorious

[church] resound with their voices.

It is a new sight that women would proclaim the Gospel,

and now be called teachers in the churches.

The object of your teaching is the wholly new world, where,

in the kingdom, men and women are equal.

Your work put the two sexes together as two lyres, and you

made men and women at once equal to sing [God's] praises. ${ }^{33}$

[13] Here Jacob of Sarug echoes Ephraem's own thought, as we find it expressed in one of his Hymns on Paradise. In Hymn VI:8 he speaks of the church, "the assembly of the saints," where each day "the medicine of life" is available, and there too he goes on to say:

The serpent (beny $\hat{a})$ is crippled and bound by the curse, while Eve's (hamwa ) mouth is sealed with a silence that is beneficial (Gen. 3:14)

32 Joseph P. Amar, "A Metrical Homily on Holy Mar Ephrem by Mar Jacob of Sarug; Critical edition of the Syriac Text, Translation and Introduction," Patrologia Orientalis 47, fasc. 1, no. 209 (Turnhout: Brepols, 1995) \#48, p. 37.

33 Amar, "A Metrical Homily on Holy Mar Ephrem," \#\# 40-4, pp. 34-5. 
-but it also serves once again

as a harp to sing the praises of her Creator. ${ }^{34}$

\section{V}

[14] The universal appeal of Ephraem's madräshê began already in the Syriac-speaking milieu in which he composed them. They were gathered into collections by theme, and also by melody, by his disciples, and by later users and transmitters of his compositions. ${ }^{35}$ In certain instances his work was even expanded by others, the better to serve some more immediate liturgical or memorial purpose. Sometimes verses and whole stanzas were rearranged to suit new situations. ${ }^{36}$ Some followers and imitators also wrote entire compositions in Ephraem's name and included them among his genuine works; others corrected or brought up to date earlier, more surely genuine pieces. ${ }^{37}$ All of this activity is testimony not only to Ephraem's popularity and authority in the Syriac-speaking churches, but also to the essentially public-service character of much of his writing. He did not write primarily tracts for scholars or meditation pieces for monks, or even literary homilies intended for circulation among the theological trend-setters. His texts were used for the most part by busy churchmen like himself, who had liturgies to celebrate or catechetical classes to teach. They often had no compunction about adapting his compositions to their own pressing purposes, or even about borrowing the authority of his name to commend a certain point of view in compositions of their own.

While it remains uncertain just how much Ephraem himself was involved in the collection of his works, it is clear that by the

${ }^{34}$ E. Beck, Des heiligen Ephraem des Syrers Hymnen De Paradiso und Contra Julianum (CSCO 174 \& 175; Louvain: Peeters, 1957) VI:8. The English translation is from Sebastian Brock, Saint Ephrem the Syrian; Hymns on Paradise (Crestwood, N.Y.: St. Vladimir's Seminary Press, 1990) 111.

35 See the remarks of G.A.M. Rouwhorst, Les hymnes pascales d'Ephrem de Nisibe, 2 vols. (Leiden: E.J. Brill, 1989), vol. I, 24-5.

36 See, e.g., B. Outtier, "Contribution à l'étude de la préhistoire des collections d'hymnes d'Éphrem," Parole de l'Orient 6 \& 7 (1975-76): 49-61.

${ }^{37}$ See, e.g., the case of the interpolated stanzas in some of the Hymns on Faith, as studied by Andrew Palmer, "Words, Silences, and the Silent Word: Acrostics and Empty Columns in Saint Ephraem's Hymns on Faith," Parole de l'Orient 20 (1995): 129-200. 
sixth century, the date of the earliest and best manuscripts, the compilations were essentially in the form in which we know them today. The evidence for the production of comprehensive volumes of Ephraem's hymns is found in remarks which occur in a number of manuscripts which transmit his works. But the principal document which has given scholars an insight into the final form taken by these volumes is Sinai Syriac MS 10, a text which in the judgment of the late and much lamented André De Halleux may have its own roots as far back as the sixth century. From this source, which is meant to be a register of the forty-five melodies used in the whole collection of Ephraem's hymns, one learns of nine volumes of the author's collected madräshê. 38

In the sixth century the appeal of these uniquely Syriac compositions already reached beyond the immediate milieu of their origins. For Ephraem's Syriac madräshâ bears an uncanny resemblance in many formal details to the Byzantine Greek Kontakion. In fact, a good case can be made for the suggestion that the most famous composer of Kontakia, Romanos the Melode (d. after 555), a native of Emesa in Syria, was actively influenced by Ephraem's madräshê. ${ }^{39}$ In this development one can see an important dimension of the appeal of Ephraem's poetry beyond his own time and place. But this appeal was not always universal.

38 See André De Halleux, "La transmission des Hymnes d’Éphrem d'après le MS. Sinai Syr. 10, f. 165v-178r," in Symposium Syriacum 1972 (Orientalia Christiana Analecta 197; Rome, 1974) 21-36; idem, "Une clé pour les hymnes d'Éphrem dans le MS. Sinai Syr. 10," Le Muséon 85 (1972): 171-99.

39 See J. Grosdidier de Matons, Romanos le Mélode et les origines de la poésie religieuse à Byzance (Paris: Beauchesne, 1977); William L. Petersen, "The Dependence of Romanos the Molodist upon the Syriac Ephrem; its Importance for the Origin of the Kontakion," Vigiliae Christianae 39 (1985): 171-87; idem, The Diatessaron and Ephrem Syrus as Sources of Romanos the Melodist (CSCO 475; Louvain: Peeters, 1985); idem, "The Dependence of Romanos the Melodist upon the Syriac Ephraem," in E. A. Livingstone (ed.), Studia Patristica XVIII, 4 (Kalamazoo, Mich.: Cistercian Publications / Leuven: Peeters, 1990), pp. 274-281; S.P. Brock, "From Ephrem to Romanos," in E. A. Livingstone (ed.), Studia Patristica XX (Leuven: Peeters, 1989) 139-51. 


\section{VI}

When Ephraem's madräshê were first translated into English, some early readers did not in fact find them all that appealing. ${ }^{40}$ For example, early in the present century F.C. Burkitt wrote:

Ephraim is extraordinarily prolix, he repeats himself again and again, and for all the immense mass of material there seems very little to take hold of. His style is as allusive and unnatural as if the thought was really deep and subtle, and yet when the thought is unraveled, it is generally commonplace. ... Judged by any canons that we apply to religious literature, it is poor stuff. ${ }^{41}$

More recently, J.B. Segal echoed the same sentiment. While admitting that Ephraem was a master of Syriac style, Segal went on to say that "his work, it must be confessed, shows little profundity or originality of thought, and his metaphors are laboured. His poems are turgid, humourless, and repetitive." 42 But in stark contrast to these negative judgments, Robert Murray has described Ephraem "as the greatest poet of the patristic age and, perhaps, the only theologian-poet to rank beside Dante." 43 And now, as if in testimony to Murray's judgment, the English composer/singer, John Tavener, has set several of Ephraem's stanzas in English translation to music and has issued a popular CD featuring them in performance. ${ }^{44}$

40 See Koonammakkal Thoma Kathanar, "Changing Views on Ephrem," Christian Orient 14 (1993): 113-30. See also the remarks of Sebastian Brock, "The Poetic Artistry of St. Ephrem: an Analysis of H. Azym. III," Parole de l'Orient 6 \& 7 (1975-76): 21-8.

${ }^{41}$ F. Crawford Burkitt, Early Eastern Christianity; St. Margaret's Lectures on the Syriac-Speaking Church (London: John Murray, 1904) 95 \& 99.

42 J.B. Segal, Edessa, 'the Blessed City' (Oxford: Oxford University Press, 1970) 89.

43 Robert Murray, "Ephrem Syrus," Catholic Dictionary of Theology, vol. II (London, 1967) 220-3. Murray reaffirmed this opinion in his landmark book, Robert J. Murray, S.J., Symbols of Church and Kingdom; a Study in Early Syriac Tradition (Cambridge: Cambridge University Press, 1975) 31.

44 John Tavener, "Thunder Entered Her," Virgin Classics, VC 5 45035 2, 1994. Ephraem's compositions, entitled "Thunder Entered Her," and "Hymns of Paradise," both in translations by Sebastian P. Brock, are pieces no. $4 \&$ no. 5 on the CD. 
[19] Undoubtedly there are many reasons behind this wide divergence of judgments in the Anglophone world about the attractiveness of Ephraem's verses, ranging from poor translations based on poor editions, to the vagaries of personal taste. But it may also be the case that readers have in some instances failed to make the distinction that Robert Murray noted some years ago between the speculative theology one expects in the works of some major patristic writers in Greek, and what many call the 'symbolic theology' of Ephraem. Murray put the point memorably when he wrote:

Ephrem refuses to answer the Arians by developing speculative theology on the orthodox side, as both Athanasius and the Cappadocians did; he sticks to his symbolism and demands that the mystery remain veiled. Not fides quaerens intellectum but fides adorans mysterium! 45

In fact no small part of the universal appeal of St. Ephraem the Syrian, especially in more recent times, has been his distrust of human rationalism as a sufficient guide to religious truth. In this connection, commentators have been fond of quoting Ephraem's words in connection with the 'Arian' controversies of his day. He wrote in his Hymns on Faith:

Blessed is the one who has not tasted the bitter poison of the wisdom of the Greeks.

Blessed is the one who has not let slip the simplicity of the apostles. ${ }^{46}$

Ephraem rejected the idea that the articles of faith could be determined by academic research, or by intellectual scrutiny that put dialectic ahead of believing. It was this position that put him on a collision course with some of the more academically inclined theologians of his day, especially in the Greek-speaking world. He spoke of the "accursed dialectic (dräshâa)" as "a hidden worm from the Greeks." 47 But by 'Greeks' (yawnàyê) Ephraem did not mean contemporary churchmen who wrote in Greek such as Athanasius

${ }^{45}$ Murray, Symbols of Church and Kingdom, 89.

${ }^{46}$ E. Beck, Des heiligen Ephraem des Syrers Hymnen de Fide (CSCO 154 \& 155; Louvain: Secrétariat du CorpusSCO, 1955) II:24.

${ }^{47}$ Beck, Hymnen de Fide, LXXXVII:4. 
(c. 300-73) or Basil (330-79). He meant those who would measure the disclosures of biblical revelation solely by the logic of the 'Hellenic' canons of reason, men such as the followers Arius (c. 260-336) or Aetius (c. 300-70), whom Greek Christian writers themselves would be inclined to call 'Hellenes'. ${ }^{48}$ Ephraem, for his part, thought that the proper posture for a Christian was an attitude of prayer and praise, arising from the contemplation of the mysteries God has strewn in both nature and scripture to lead the human mind to divinity. This line of thinking has endeared Ephraem to many generations of Christians, and it found its most beautiful and fetching expression in the poetry of his madräshê, the "teaching songs," to use Andrew Palmer's apt phrase for them, ${ }^{49}$ which have found a welcome reception in the post-modern world, so tired of rationalism, but deeply drawn to the revelatory power of metaphor and symbol.

\section{VII}

According to Ephraem, what one finds in Nature and Scripture are the types and symbols, along with the names and titles, by means of which the invisible God reveals himself to the eyes and minds of persons of good faith, and which prepare them to recognize the incarnate Word of God in Jesus of Nazareth. In one stanza from his Hymns on Virginity he says the following about the incarnate Son and his symbols and types:

In every place, if you look, his symbol is there, and wherever you read, you will find his types.

For in him all creatures were created and he traced his symbols on his property.

When he was creating the world, he looked to adorn it with icons of himself.

48 See A. Garzya, "Visages de l'Hellénisme dans le monde byzantin," Byzantion 55 (1985): 463-82.

${ }^{49}$ See Palmer's insightful study of a selection of Ephraem's hymns De Fide in Andrew Palmer, "The Merchant of Nisibis; Saint Ephrem and his Faithful Quest for Union in Numbers," in J. Den Boeft \& A. Hilhorst, Early Christian Poetry; a Collection of Essays (Supplements to Vigiliae Christianae XXII; Leiden: E.J. Brill, 1993) 167-233. 
The springs of his symbols were opened up to run down and pour forth his symbols into his members. ${ }^{50}$

Similarly, in one of his hymns for the liturgy of Maundy Thursday Ephraem speaks of the symbols and types of God's Son and Messiah to be found in the scriptures. He says, in allusion to the 'Arianism' which he combats in so many of his texts:

Those doctrines are put to shame which have alienated the Son.

See, the Law carries all the liknesses of him.

See, the Prophets, like deacons, carry the icons of the Messiah.

Nature and Scripture together carry the symbols of his humanity and of his divinity. ${ }^{51}$

What Ephraem commends to the spiritually starved is nothing less than the prayerful practice of lectio divina, allied with an appropriate sense of intellectual humility. In one stanza of the Hymns on Faith he gives this advice:

Let us not allow ourselves to go astray and to study our God.

Lest us take the measure of our mind, and gauge the range of our thinking.

Let us know how small our knowledge is, too contemptible to scrutinize the Knower of All. ${ }^{52}$

The fact is, according to Ephraem, there is a deep chasm (pelptâ) between God and his creatures, which human knowledge cannot bridge, but which love crosses. ${ }^{53}$ God, for his part, as a

${ }^{50}$ E. Beck, Des heiligen Ephraem des Syrers Hymnen de Virginitate (CSCO 223 \& 224; Louvain: Peeters, 1962) XX:12.

${ }^{51}$ E. Beck, Des heiligen Ephraem des Syrers Paschabymnen; (de Azymis, de Crucifixione, de Resurrectione) (CSCO 248 \& 249; Louvain: Peeters, 1964), De Azymis, IV:22-4.

${ }^{52}$ Beck, Hymnen de Fide, XV:3.

53 See Beck, Hymnen de Fide, LXIX:11-2. See also the study of this facet of Ephraem's thought in Thomas Koonammakkal, “The Theology 
function of His love for us, has provided for us, in human language, the symbols and types, the names and metaphors, culminating in the Incarnate Son, by which we may cross over to Him. Ephraem makes this point clearly in a prayer he addresses to Jesus as the final strophe in an acrostic madräshâ which ends with the middle letter of the Syriac alphabet, yodh, which is also the first letter of the name 'Jesus' (Yesh $\left.\hat{\imath}^{c}\right)$. He says,

O Jesus, glorious name,

hidden bridge which carries one over

from death to life,

I have come to a stop with you;

I finish with your letter yodh.

Be a bridge for my words to cross over to your truth.

Make your love a bridge for your servant.

By means of you I shall cross over to your Father.

I will cross over and say, 'Blessed is the One

who has made his might tender in his offspring. ${ }^{54}$

The scriptures too are a bridge over the chasm that separates man from God, and in one of his Hymns on Paradise, as he describes his reading of the book of Genesis, Ephraem provides the perfect paradigm for the contemplative Christian at prayer, Bible in hand. He says,

I read the opening of this book and was filled with joy,

for its verses and lines

spread out their arms to welcome me;

the first rushed out and kissed me,

and led me on to its companion;

and when I reached that verse

wherein is written

the story of Paradise,

it lifted me up and transported me

of Divine Names in the Genuine Works of Ephraem," (D. Phil. thesis presented to the University of Oxford, Oxford, 1991).

${ }^{54}$ Beck, Hymnen de Fide, VI:17. For a discussion of the full range of 'bridge' imagery in Ephraem's writing see E. Beck, 'Zwei ephrämische Bilder," Oriens Christianus 71 (1987): 1-9. 
from the bosom of the book

to the very bosom of Paradise.

The eye and the mind

traveled over the lines

as over a bridge, and entered together

the story of Paradise.

The eye as it read

transported the mind;

in return the mind, too,

gave the eye rest

from its reading,

for when the book had been read

the eye had rest

but the mind was engaged.

Both the bridge and the gate

of Paradise

did I find in this book.

I crossed over and entered;

my eye remained outside

but my mind entered within.

I began to wander

among things indescribable.

This is a luminous height,

clear, lofty and fair:

Scripture named it Eden, the summit of all blessings. ${ }^{55}$

\section{VIII}

While Ephraem was thus a master poet of the spiritual life, a biblical exegete, and even a religious polemicist of considerable acumen, ${ }^{56}$ he was also a spiritual father, psychologically astute,

${ }^{55}$ E. Beck, Des heiligen Ephraem des Syrers Hymnen De Paradiso und Contra Julianum (CSCO 174 \& 175; Louvain: Peeters, 1957) V:2-5. The English translation is from S. Brock, Saint Ephrem the Syrian; Hymns on Paradise (Crestwood, N.Y.: St. Vladimir's Seminary Press, 1990) 102-4.

${ }^{56}$ See Sidney H. Griffith, "Setting Right the Church of Syria: Saint Ephraem's Hymns against Heresies," in William E. Klingshirn \& Mark Vessey (eds.), The Limits of Ancient Christianity: Essays on Late Antique 
whose counsels were widely esteemed. It was this quality, as much as any other, that contributed to his universal appeal. For in the texts attributed to Ephraem that circulated so widely outside of the Syriac-speaking milieu, in almost all the languages of the late antique and medieval Christian world, especially in the monastic communities where the icon of Ephraem Byzantinus was cherished, advice for spiritual direction predominated. A case in point is the so-called Sermo Asceticus, one of those works ascribed to Ephraem Graecus, which, in the form in which it survives in Greek, is to be found translated into almost all the languages of early and medieval Christianity. As has been remarked, it is "one of Ephraem's most read and most abused writings" 57 -abused in the sense that many writers in many languages have made it their own by adding to it, shortening it, and even moving its paragraphs around.

There are Latin, Coptic, Georgian, Arabic, Armenian, Ethiopic, and Slavonic versions of the Sermo Asceticus known to scholars, and in what seems to be its original Greek, almost twenty passages from it have so far been found included in other texts attributed to Ephraem Graecus. ${ }^{58}$ Latin sources from as early as the seventh century can be cited in attestation of the Sermo Asceticus as a work of Ephraem. The late seventh century monk of Ligugé, Defensor, quotes from it some nine times in his Liber Scintillarum, an ascetical compilation which had a very wide circulation in monasteries in the west throughout the Middle Ages. ${ }^{59}$ In addition to the Greek text, and the Latin translation, the Sermo Asceticus has also been published in its Coptic version, from a manuscript of the tenth century, together with an English translation. ${ }^{60}$ The manuscript was written in the year 973 A.D. at the Monastery of Saint Macarius of Idfu in Egypt. But its Coptic version includes only about twothirds of the original Greek text.

Thought and Culture in Honor of R.A. Markus (University of Michigan Press, Ann Arbor, 1999) (Forthcoming).

57 J. Kirchmeyer \& D. Hemmerdinger-Iliadou, "Saint Éphrem et le 'Liber Scintillarum'," Recherches de Science Religieuse 46 (1958): 549.

${ }^{58}$ See Geerard, Clavis Patrum Graecorum, 370-3.

${ }^{59}$ See Kirchmeyer \& Hemmerdinger-Iliadou, "Saint Éphrem et le 'Liber Scintillarum',' 546-9.

${ }^{60}$ E.A. Wallis Budge, Coptic Matryrdoms Etc. in the Dialect of Upper Egypt (London: British Museum, 1914) 157-78 (Coptic); 409-30 (English). 
The Sermo Asceticus is an extended homily addressed to the monastic estate at large. There are no specifics in it which might identify either the author or the particular community to whom he spoke, or for whom he wrote. The author speaks in the first person, and addresses the audience in the plural as 'brethren' ( $\alpha \delta \varepsilon \lambda \phi o \hat{\imath})$, or 'beloved' ( $\alpha \gamma \alpha \pi \eta \tau o \hat{})$, or occasionally as 'monks'

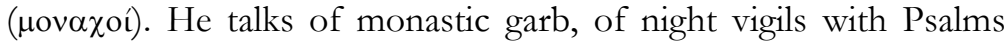
and hymns, and of extended prayer and penance. A typical, exhortatory passage is the following one:

O brethren, let us humble our souls with fasting and with sorrow, and with vigils by night, and let us walk in the truth. ... Let us mourn, so that the Holy Spirit may comfort us ... especially we who have been made to be worthy of the conversation of the angels. ${ }^{61}$

The author is concerned about what he regards as the decadent situation of the life of the monks of his day. He complains that "the word of instruction has ceased to prevail in our time, and that inasmuch as we are in a state of ignorance our sins have multiplied." 62 The Sermo Asceticus exhorts the monks to return to the teachings of the fathers. Several times the readers are reminded

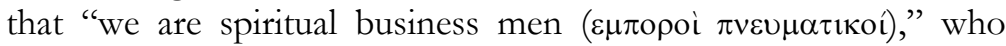
should be concerned solely to seek the pearl of great price. The 'habit does not make the monk,' the writer maintains, but only the work of the truly moderate on who has learned to enjoy the gifts of nature in the measure the Creator intended, and not according to the appetites instilled in humans by habits of sin.

Of the thirty columns of Greek text which it takes for the printing of the Sermo Asceticus in Assemani's edition, ${ }^{63}$ only ninetytwo lines of it can be found to be translated from a Syriac original. ${ }^{64}$ That is to say, there was a Syriac Vorlage for only a small part of it. Moreover, the nine translated passages are for the most part brief, containing only a few lines; the longest continuous passage, however, includes forty-three lines, almost half the total. The translated passages are distributed throughout the work, and hence, with the exception of the long one, they are not

${ }^{61}$ Wallis Budge, Coptic Martyrdoms, 413.

62 Wallis Budge, Coptic Martyrdoms, 409.

${ }^{63}$ Assemani, Ephraem Opera Omnia, vol. I, 40-70.

${ }^{64}$ See the citations given in Geerard, Clavis Patrum Graecorum, 371. 
concentrated on a single point. They are in no way set apart, but are completely integrated into the discourse. It is only the discerning eye of the modern scholar, searching for evidence of the Syriac Vorlagen of the work, which has discovered them and set them apart.

The Syriac works attributed to Ephraem the Syrian from which the translated passages in the Sermo Asceticus come are two: the so-called Sermo de Reprehensione and the Sermo de Confessoribus et Martyribus. Both of these texts are available in modern editions. ${ }^{65} \mathrm{In}$ a couple of instances the same passage quoted in the Sermo Asceticus appears in more than one Syriac work attributed to Ephraem. This circumstance recalls the somewhat fluid state of some texts attributed to Ephraem in the fifth and sixth centuries, when in the Graeco-Syrian monastic communities in the Syriac-speaking world the major collections of the Syriac works of Ephraem were being assembled. In some instances editors and compilers somewhat arbitrarily shifted verses by Ephraem from collection to collection, and sometimes they completed one compilation with lines by other writers done in the style of Ephraem and on themes favored by him. This kind of activity is testimony not only to Ephraem's popularity and authority in the Syriac-speaking churches, but also to the essentially public-service character of much of his writing. Later people who used his work saw no reason why they should not adapt it to their immediate purposes; some of them composed whole works in the style of Ephraem.

In regard to the two Syriac works from which quotations are drawn in the Sermo Asceticus, it is the current scholarly opinion that the portions of the De Reprehensione quoted in the text do in fact come from the pen of Ephraem. ${ }^{66}$ On the other hand, it seems that the hymns De Confessoribus attributed to Ephraem in the manuscript

65 The Sermo de Reprehensione is published in T. J. Lamy, Sancti Ephraem Syri Hymni et Sermones, vol. IV (Mechliniae, 1902) 265-356; E. Beck, Des heiligen Ephraem des Syrers Sermones I (CSCO 305 \& 306; Louvain, 1970), vol. 305, 12-49 (Syriac), vol. 306, 17-65 (German). The Sermo de Confessoribus is published in T. J. Lamy, Sancti Ephraem Syri Hymni et Sermones, vol. III (Mechliniae, 1889) 643-750; E. Beck, Nachträge zu Ephraem Syrus (CSCO, 363-4; Louvain, 1975), vol. 363, 1-19 (Syriac); vol. 364, 1-25 (German).

66 So the opinion of Beck: "So finde ich auch hier keine Schwierigkeiten, die die Echtheit dieses handschriftlich sehr gut bezeugten Sermo in Frage stellen könnten.” Beck, Sermones I, vol. 306, viii. 
tradition were actually composed in the generation after his lifetime by writers consciously working on the model of his style and concerns. ${ }^{67}$ So it turns out that for the most part the Sermo Asceticus has nothing much literally to do with the authentic Syriac works of Ephraem, with the exception of several phrases quoted in Greek translation from the Sermo de Reprehensione. And yet, the work often breathes with the spirit of Ephraem, sometimes using words and phrases with a distinctly Ephraemian ring to them, although the composition as a whole is cast in a monastic framework that would have been unfamiliar to Ephraem.

This does not mean that the Sermo Asceticus is simply a forgery and that the Ephraem known in the monastic communities of the east and west in the Middle Ages and in modern times has no connection at all with the Syriac-speaking 'teacher' (malpanna and melodist of Nisibis and Edessa. Rather, it seems more reasonable to see the Greek compositions and their many versions as a natural outgrowth of the tendency that began already in Ephraem's lifetime for those deeply affected by him not only to collect his work and make compilations of it in the original language, but to adapt his insights and teachings to ever new settings and new languages, often preserving only the acuity of his spiritual insights, clothed in a completely unfamiliar idiom. In other words, one can see in the numerous productions of Ephraem Graecus, the beginnings of the universal appeal of St. Ephraem the Syrian, filtered through a new fashion of Christian spirituality, which grew steadily from its origins in the Egyptian deserts and elsewhere in the fourth century, until the point when expressions attributed to Ephraem in the new mode, and often encapsulating his insights, reached virtually a canonical status by their not infrequent quotation in texts included in the Philokalia, in the work of Peter Damaskenos (fl. c. 1156/7). ${ }^{68}$ In this way St. Ephraem the Syrian became in fact a spiritual father for the whole church. Even Pope Benedict XV, who declared him

67 Beck says, "die nicht wenigen sachlichen Abweichungen von Ephräm gegen seine Autorschaft sprechen. ... Die Schrift für eine Fälschung der ersten Generationen nach Ephräm zu halten." Beck, Nachträge, vol. 364, vii.

${ }^{68}$ See G.E.H. Palmer, Philip Sherrard, Kallistos Ware (eds. et trans.), The Philokalia; the Complete Text Compiled by St Nikodimos of the Holy Mountain and St. Makarios of Corinth, 3 vols. (London: Faber \& Faber, 1979-84), vol. III, 70-281. 
a Doctor of the Universal Chruch, marvelled that "holy and orthodox fathers and doctors, from Basil, Chrysostom and Jerome, to Francis de Sales and Alphonsus Liguori," could sing Ephraem's praises in one voice. ${ }^{69}$

\section{IX}

[35] It is not appropriate to end these reflections on the universal appeal of St. Ephraem the Syrian without ourselves asking for a word of advice from so widely esteemed a spiritual father. For this purpose I have chosen a passage from his second mêmrâ "On Reproof," from the same material that so inspired the composer of the Greek Sermo Asceticus. Ephraem wrote:

Let us be builders of our own minds into temples suitable for God.

If the Lord dwells in your house, honor will come to your door.

How much your 'honor' will increase if God dwells within you.

Be a sanctuary for him, even a priest, and serve him within your temple.

Just as for your sake he became High priest, sacrifice, and libation;

you, for his sake, become temple, priest, and sacrificial offering.

Since your mind will become a temple, do not leave any filth in it;

do not leave in God's house anything hateful to God.

Let us be adorned as God's house, with what is attractive to God.

If anger is there, lewdness abides there too; if rage is there, fumes will rise up from there.

Expel grudges from there, and jealousy, whose reek is abhorent.

Bring in and install love there,

${ }^{69}$ Benedict XV, "Principi Apostolorum Petro," 459. 
as a censer full of fragrant incense.

Gather up and take the dung out, odious liaisons and bad habits.

Strew good fellowship around it, like blossoms and flowers.

But instead of roses and lilies, decorate it with prayers. ${ }^{70}$

${ }^{70}$ Beck, Sermones I, II:93-124. 